\title{
REPRESENTASI GENERASI MILENIAL DALAM ANIMASI DALANG PELO: TINJAUAN ASPEK NARASI DAN VISUAL
}

\author{
Lestari Kusuma Dewi', Aswan ${ }^{2}$ \\ 1,2 Departemen Pendidikan Bahasa dan Sastra Indonesia, Universitas Pendidikan Indonesia \\ Korespondensi: Jalan Dr. Setiabudhi Nomor 229 Bandung, Jawa Barat \\ Surel: lestarikudew@upi.edu
}

\section{INFO ARTIKEL}

Sejarah Artikel:

Diterima: 05/01/2021

Direvisi: 19/01/2021

Dipublikasikan: 30/01/2021

e-ISSN: 2721-0995

p-ISSN: 2721-9046

\section{Kata Kunci:}

Generasi Milenial

Film Animasi

Aspek Narasi

Aspek Visual

Keywords:

Millennial Generation

Animated Films

Narrative Aspects

Visual Aspects
ABSTRAK Representasi Generasi Milenial dalam Animasi Dalang Pelo: Tinjauan Aspek Narasi dan Visual. Setiap animator memiliki ciri khas dalam membingkai cerita dan visual pada film animasinya. Fenomena ini menarik untuk diteliti mengingat saat ini yang mendominasi film animasi adalah generasi milenial. Penelitian ini bertujuan untuk mendeskripsikan generasi milenial direpresentasikan oleh animasi Dalang Pelo. Penelitian ini menggunakan metode penelitian kualitatif dengan pendekatan deskriptif sebagai pisau analisis. Temuan dalam penelitian ini adalah representasi generasi milenial melalui aspek naratif dan visual dalam film animasi Dalang Pelo. Animator merepresentasikan narasi cerita dalam animasi dibuat sederhana dengan 3 babak. Hal ini menunjukkan generasi milenial yang kurang menyukai hal-hal yang rumit. Temuan dari segi aspek sinematografi digunakan untuk mendukung fungsi dramatik. Penyampaian narasi dan tema cerita ke dalam animasi itu kepada para penonton khususnya generasi milenial dimaksudkan agar penonton mudah terbawa perasaan sehingga dapat menikmati ceritanya.

\footnotetext{
ABSTRACT

Representation of Millennial Generation in Dalang Pelo's Animation: An Overview of Narrative and Visual Aspects. Each animator has a characteristic in framing the story and visuals in their animated film. This phenomenon is interesting to study considering that currently the millennial generation dominates animated films. This study aims at describing how the millennial generation is represented by the animation of Dalang Pelo. This study uses a qualitative research method with a descriptive analysis. The findings in this study are the representations of the millennial generation through narrative and visual aspects in the animated film Dalang Pelo. The animator represents the narrative story in a simple animation with three acts, and this shows that the millennial generation does not like complicated things. Findings from the aspect of cinematography are used to support dramatic functions, narrative delivery, and story themes in animation that viewers, especially the millennial generation, who tend to be easily carried away with feelings can enjoy the story.
} 


\section{PENDAHULUAN}

Film animasi saat ini menjadi salah satu media dalam menyampaikan pesan atau amanat melalui audio visual. Hasbullah dan Yasa (2020) mengatakan hal yang sama bahwa film animasi merupakan salah satu bagian dari budaya visual. Budaya visual ini dikatakan dapat menginformasikan berbagai pesan melalui audio dan visual sebagai bahan bakunya. Pesan yang disampaikan dapat berupa propaganda, bujukan, imbauan, dan sebagainya. Senada dengan itu, Putra dan Saputra (2017) mengungkapkan bahwa keberadaan film animasi ini menjadi salah satu budaya media yang dapat menunjang wacana yang berada pada bidang ekonomi kreatif. Contoh konkretnya dapat dilihat pada variasi visual atau efek yang dapat ditemukan pada film animasi.

Fenomena film animasi di Indonesia sudah tidak asing lagi bagi masyarakat Indonesia. Berbagai jenis film animasi dapat ditemukan saat ini. Misalnya, film animasi berbentuk dua dimensi atau namanya lainnya dwimatra, tiga dimensi atau trimatra. Bahkan, film animasi campuran antara dwimatra dan trimatra pun ada. Jenis film animasi seperti ini tergolong umum dan sering dikonsumsi oleh masyarakat pencinta film animasi (Djalle, 2006; Hendriana, dkk. 2016; Sangian \& Lumenta, 2017). Adapun perkembangan film animasi tidak akan pernah lepas dari karakteristik bangsa, etnis, kelas sosial, gender, dan komunitas (Khalis, dkk. 2016). Namun seiring berjalannya waktu, film animasi berkembang sesuai arus teknologi serta globalisasi sehingga kearifan lokal sedikit demi sedikit memudar (Lestari \& Setiawan, 2019).

Melihat fenomena film animasi saat ini, peneliti tertarik untuk mengetahui cara generasi milenial direpresentasikan dalam sebuah film animasi. Asumsi peneliti ini berdasarkan pada pendapat Muhdaliha dan Batuaya (2017) yang mengatakan animasi memiliki unggulan dalam merepresentasikan realitas serta meta-realitas dalam sajian imajinatif. Sajian tersebut dipaparkan melalui teknik visual yang beragam, seperti penggunaan efek dan sebagainya. Hal ini membuat peneliti tertarik untuk mengkaji bagaimana generasi milenial direpresentasikan pada film animasi Dalang Pelo.

Film animasi Dalang Pelo masih jarang diteliti baik dari segi aspek visual maupun narasinya. Adapun penelitian terdahulu mengenai Dalang Pelo pernah diteliti oleh Putri dan Candraningrum (2019) dengan judul Pemanfaatan Social Traffic untuk Meningkatkan Page Views pada Video "Gagas Isengin Acil! Leri Marah" di Akun Youtube dan Instagram Dalang Pelo. Penelitian ini masih terbatas dalam ruang lingkup sosial media sehingga bagian visual dan narasi film animasi Dalang Pelo belum dikaji.

Penelitian khusus yang mengkaji aspek visual dan narasi dalam sebuah film animasi pernah diteliti oleh Othman (2009) dengan judul Film Animasi Malaysia: Narasi Verbal ke Visual. Penelitian ini mengungkapkan bahwa dalam narasi verbal terjadi penggabungan ide, media, teknik, dan ekspresi karya seni yang kemudian ditransformasikan menjadi makna dan lambang-lambang sebagai simbolisme. Lambang-lambang ini kemudian disampaikan nilainilai atau norma masyarakat pada saat ditransformasikan ke dalam bentuk visual imajinatif. Adapun narasi visual terbentuk melalui proses yang sama yakni penumpukan ide, teknik, 
ekspresi, perubahan media ke dalam bentuk animasi. Melihat penelitian terdahulu tersebut dapat dikatakan bahwa topik yang peneliti angkat ini masih relevan dan belum pernah diteliti. Berdasarkan fenomena dan latar belakang yang sudah dipaparkan, penelitian ini layak dan penting untuk dilakukan mengingat film animasi saat ini berkembang sangat pesat.

\section{TINJAUAN PUSTAKA}

Generasi Milenial

Generasi milenial adalah generasi yang lahir di antara tahun 1980-2000 saat terjadi kemajuan teknologi yang pesat. Jika dilihat dari kelompok umur, generasi milenial merupakan generasi yang saat ini berusia dikisaran 15-34 tahun (Hidayatullah, dkk, 2018). Generasi milenial beberapa tahun belakang ini menjadi fenomena yang tidak bisa dihindari. Bagi yang aktif di media sosial tentu saja sudah akrab dengan istilah generasi milenial. Media sosial disinyalir yang membesarkan "nama" generasi milenial ini (Sari, 2019). Sejalan dengan pendapat tersebut, Poluakan, dkk. (2019) menyebutkan bahwa generasi milenial (generasi $Y$ atau millennial generation) sudah berinteraksi dengan teknologi sejak lahir. Sederhananya, generasi ini identik dengan teknologi (Sabani, 2018; Ambarwati \& Raharjo, 2018; Roza, 2020). Generasi ini banyak menggunakan teknologi komunikasi instan, seperti: e-mail, SMS (Short Message Service), instant messaging, dan media sosial lainnya seperti Facebook dan Twitter, juga online game.

Suryadi (2015) menggambarkan karakteristik generasi milenial terbuka terhadap hal-hal baru, selalu ingin tampil beda dari yang lain, menggunakan kreativitasnya untuk menciptakan sesuatu yang baru, menyukai suasana kerja yang santai dan mampu mengerjakan beberapa hal secara bersamaan (multi-tasking), peduli terhadap gaya (style), dan cepat beradaptasi dengan teknologi. Sayangnya, generasi ini gampang bosan dan loyalitasnya dalam urusan pekerjaan terbilang kurang.

Aspek Narasi dan Visual dalam Film Animasi

Film animasi sebagai bagian dari budaya visual difungsikan untuk menginformasikan atau menyampaikan pesan berupa imbauan, propaganda, bujukan, dan lainnya. Animator menyelipkan pesan yang ingin disampaikan melalui kode-kode (bahasa visual). Pesan tersebut dapat dilihat melalui kode visual dalam setiap adegan (scene). Kode-kode yang disepakati secara sosial dalam kehidupan sehari-hari biasanya menjadi budaya dalam hidup seperti: gerak tubuh, pakaian, aksesori, tempat dan lain sebagainya (Hasbullah \& Yasa, 2020). Sejalan dengan pendapat tersebut, Winarni \& Wardani (2015) menyebutkan visualisasi di dalam film animasi adalah bentuk tanda-tanda dari aktivitas budaya manusia yang dapat membangun persepsi tertentu di masyarakat. Oleh karena itu, penciptaan narasi visual dengan karakter-karakter tokoh di dalamnya, harus dapat berelasi dengan nilai-nilai sosial dan budaya masyarakat di tempat animasi diproduksi dan dipublikasikan. 


\section{METODE}

Pendekatan yang digunakan dalam penelitian ini adalah penelitian kualitatif. Metode penelitian ini dipilih berdasarkan tujuan penelitian yaitu ingin mengkaji representasi generasi milenial yang berfokus pada aspek narasi dan visual. Sesuai hakikat dari penelitian kualitatif yaitu tidak menggunakan analisis statistika tetapi mendeskripsikan fenomena (Moleong, 2012). Hal ini sejalan dengan pendapat dari Creswell (2009) bahwa penelitian kualitatif sejatinya untuk mengeksplorasi dan memahami subjek dan objek penelitian.

Objek penelitian ini adalah film animasi Dalang Pelo "Gagas Isengin Acil! Leri Marah! Dalang Pelo". Adapun tahapan penelitian dimulai dari mengunduh data, menonton, mencatat poin-poin penting, melakukan analisis, dan membuat kesimpulan. Adapun teknik analisis data menggunakan pendekatan deskriptif dengan mendeskripsikan data dengan bahasa yang sederhana dan mudah dipahami. Fokus penelitian ini adalah untuk mendeskripsikan aspek naratif dan visual dari film animasi Dalang Pelo.

\section{HASIL DAN PEMBAHASAN}

\section{Temuan Data Film Animasi Dalang Pelo}

Tabel 1. Identitas Film Animasi Dalang Pelo

\begin{tabular}{|l|l|}
\hline Judul Film & $\begin{array}{l}\text { Gagas Isengin Acil! Leri Marah!-Dalang } \\
\text { Pelo }\end{array}$ \\
\hline Genre & Animasi, Komedi \\
\hline Tanggal Publikasi & 5 Oktober 2019 \\
\hline Durasi & $1: 35$ \\
\hline Kanal Youtube & Dalang Pelo \\
\hline Animator & Nur Alif Ramadhan \\
\hline Tokoh Animasi dan Pengisi Suara & $\begin{array}{l}\text { Acil, Leri, Gagas, Pak Guru (Nur Alif } \\
\text { Ramadhan) }\end{array}$ \\
\hline
\end{tabular}

Film animasi Dalang Pelo merupakan film yang dibuat oleh Nur Alif Ramadhan. Nur Alif Ramadhan atau yang kerap disapa "Acil" mulai membuat animasi Dalang Pelo di tahun 2016 sejak kelas 1 SMK. Awalnya, ia tak mengetahui apapun tentang animasi, tetapi ia sangat suka menggambar. Cerita yang dihadirkan dalam animasi ini bertema milenial karena sangat dekat dengan kehidupan remaja masa kini yang sudah sering viral. Menariknya, ia membuat animasi Dalang Pelo sendirian, mulai dari membuat naskah, mengedit animasi, sampai menjadi pengisi suara. Hingga kini, kanal Youtube Dalang Pelo sudah mencapai 3,58 juta pengikut (subscriber).

\section{Sinopsis Film}

Acil dan Leri sedang berada di sekolah. Saat pak guru memulai pelajaran, Gagas tibatiba melempar pensil ke kepala Acil sambil meledeknya. Ketika melihat kejadian itu, Leri yang duduk di samping Acil marah. Akhirnya, Acil dan Leri membalas keisengan Gagas, Acil menggunakan jurus tembakan super sampai Gagas dihukum pak guru. 
Segmentasi Adegan dalam Film

Tabel 2. Segmentasi Adegan Film Animasi Dalang Pelo

\begin{tabular}{|c|l|l|l|}
\hline Adegan/Scene & Waktu & Reviu & Latar \\
\hline Pembuka & $00.00-00.02$ & Pembukaan "Judul" & $\begin{array}{l}\text { Ruang Kelas } \\
\text { Pagi hari }\end{array}$ \\
\hline 1. & $00.03-00.11$ & $\begin{array}{l}\text { Acil bernyanyi dan balasan ketus } \\
\text { dari Leri }\end{array}$ & $\begin{array}{l}\text { Ruang Kelas } \\
\text { Pagi hari }\end{array}$ \\
\hline 2. & $00.13-00.16$ & $\begin{array}{l}\text { Sapaan dari Pak Guru untuk } \\
\text { memulai pelajaran }\end{array}$ & $\begin{array}{l}\text { Ruang Kelas } \\
\text { Pagi hari }\end{array}$ \\
\hline 3. & $00.17-00.27$ & $\begin{array}{l}\text { Gagas mengisengi Acil dan Leri } \\
\text { marah. }\end{array}$ & $\begin{array}{l}\text { Ruang Kelas } \\
\text { Pagi hari }\end{array}$ \\
\hline 4. & $00.28-00.37$ & $\begin{array}{l}\text { Acil dan Leri dipukul oleh Pak } \\
\text { Guru karena Gagas melaporkan } \\
\text { mereka berisik. }\end{array}$ & $\begin{array}{l}\text { Ruang Kelas } \\
\text { Pagi hari }\end{array}$ \\
\hline 5. & $1.19-1.28$ & $\begin{array}{l}\text { Pak Guru memarahi Gagas yang } \\
\text { tidur di kelas dan Gagas dihukum. } \\
\text { Acil dan Leri akhirnya menang. }\end{array}$ & $\begin{array}{l}\text { Ruang Kelas } \\
\text { Pagi hari }\end{array}$ \\
\hline 5. & $00.38-1.09$ & $\begin{array}{l}\text { Acil dan Leri menyusun rencana } \\
\text { Antuk membalas keisengan Gagas. } \\
\text { Akhirnya mereka saling tembak. }\end{array}$ & $\begin{array}{l}\text { Ruang Kelas } \\
\text { Pagi hari }\end{array}$ \\
\hline Penutup & $1.29-1.35$ & $\begin{array}{l}\text { Acil mengeluarkan jurus } \\
\text { tembakannya. }\end{array}$ & $\begin{array}{l}\text { Ruang Kelas } \\
\text { Pagi hari }\end{array}$ \\
\hline tembangang Kelas \\
\hline
\end{tabular}

\section{Segmentasi Adegan dalam Sekuen Film}

Tabel 3. Segmentasi Adegan dalam Sekuen Film Animasi Dalang Pelo

\begin{tabular}{|l|c|c|}
\hline \multicolumn{1}{|c|}{ Sekuen } & Adegan & Pelaku Cerita \\
\hline $\begin{array}{l}\text { 1. Nyanyian Acil yang dibalas ketus oleh } \\
\text { Leri }\end{array}$ & Adegan 1 & Acil dan Leri \\
\hline $\begin{array}{l}\text { 2. Sapaan dari Pak Guru untuk memulai } \\
\text { pelajaran }\end{array}$ & Adegan 2 & Pak Guru \\
\hline 3. Gagas mengisengi Acil dan Leri marah & Adegan 3 & Acil, Leri, dan Gagas \\
\hline
\end{tabular}




\begin{tabular}{|l|c|c|}
\hline $\begin{array}{l}\text { 4. Pak Guru memukul Leri dan Acil } \\
\text { akibat keisengan Gagas }\end{array}$ & Adegan 4 & $\begin{array}{c}\text { Acil, Leri, Gagas dan Pak } \\
\text { Guru }\end{array}$ \\
\hline $\begin{array}{l}\text { 5. Leri dan Acil membalas perbuatan } \\
\text { Gagas dan mereka saling menembak. }\end{array}$ & Adegan 5 & Acil dan Leri \\
\hline $\begin{array}{l}\text { 6. Acil mengeluarkan jurus } \\
\text { menembaknya }\end{array}$ & Adegan 6 & Acil dan Gagas \\
\hline 7. Gagas pingsan karena tembakan Acil & Adegan 7 & Gagas \\
\hline $\begin{array}{l}\text { 8. Pak Guru menghukum Gagas } \\
\text { sehingga Acil dan Leri menjadi } \\
\text { pemenang }\end{array}$ & Adegan 8 & $\begin{array}{c}\text { Acil, Leri, Gagas, dan Pak } \\
\text { Guru }\end{array}$ \\
\hline
\end{tabular}

\section{Analisis Struktur Naratif Film Animasi Dalang Pelo}

\section{Pola Struktur Cerita}

Pola pengembangan struktur naratif film animasi Dalang Pelo ini dikembangkan dari pola struktur tiga babak yang terdiri atas tahap permulaan (persiapan), tahap pertengahan (konfrontasi), dan tahap penutupan (resolusi).

Tabel 4. Struktur Tiga Babak Film Animasi Dalang Pelo

\begin{tabular}{|c|c|}
\hline Babak & Sekuen \\
\hline Permulaan (persiapan) & Sekuen 1 \\
\hline Pertengahan (konfrontasi) & Sekuen 2 \\
\hline Penutupan (resolusi) & Sekuen 3 \\
\hline
\end{tabular}

Pada babak permulaan, cerita diarahkan pada situasi yang gembira, yaitu pada saat Acil bernyanyi lagu sekolah untuk Leri yang ia sayang meskipun dibalas Leri dengan ungkapan ketus. Kemudian, Pak Guru menyapa murid-muridnya untuk memulai pelajaran Ilmu Pengetahuan Alam. Dalam adegan tersebut nuansa humor diangkat dalam lagu yang dinyanyikan Acil untuk Leri. Durasi babak permulaan ini sekira 17 detik.

Selanjutnya, babak pertengahan cerita dimulai ketika Gagas mengisengi Acil dengan melempar pensil ke kepalanya sambil meledeknya dan Leri marah, karena keisengan Gagas juga, Acil dan Leri dipukul Pak Guru. Acil dan Leri yang merasa kesal membalas perbuatan Gagas. Akhirnya mereka saling menembak. Durasi babak pertengahan ini sekira 51 detik.

Babak penutupan dimulai saat Acil mengeluarkan jurus menembaknya. Gagas yang merasa jijik akhirnya pingsan. Pak Guru menyangka Gagas tertidur di kelas. Akhirnya, Gagas dihukum. Leri dan Acil menjadi pemenang. Dalam adegan ini, nuansa humornya tercipta dari dialog Acil saat mengeluarkan jurus menembaknya. Durasi babak penutup ini sekira 27 detik.

\section{Hubungan naratif dan ruang}

Cerita dalam film animasi Dalang Pelo ini mengambil ruang-ruang kehidupan yang ada di kehidupan nyata, yakni di ruang kelas.

\section{Hubungan Naratif dan Waktu}

Hubungan naratif dan ruang waktu dalam film animasi Dalang Pelo menggunakan 
urutan waktu (temporal order). Film animasi Dalang Pelo ini menggunakan urutan waktu dengan pola linear. Pola ini menunjukkan bahwa cerita animasi Dalang Pelo ini bergerak maju dari satu adegan ke adegan berikutnya.

\section{Durasi waktu (Pembagian Durasi Peradegan)}

Durasi fim ini berlangsung selama 1 menit 35 detik dengan pembagian durasi waktu pada setiap babaknya adalah 17 detik untuk babak permulaan, 51 detik untuk babak pertengahan, dan 27 detik untuk penutupan. Sementara itu, ada intro atau pembukaan selama 2 detik di awal untuk memberikan sketsa informasi mengenai tayangan dan di akhir ada kompilasi konten lainnya yang wajib ditonton juga permintaan dari konten kreator yang mengajak penonton berlangganan di kanal Youtube tersebut.

\section{Batasan Informasi Cerita}

Cerita dalam film Animasi Dalang Pelo menggunakan kombinasi jenis penceritaan tak terbatas (Omniscient Narration). Penonton diberi kebebasan untuk mengetahui informasi lain dalam setiap adegan yang dipertontonkan dengan sudut pandang yang menyeluruh.

1. Ruang/Latar Film Animasi Dalang Pelo

Ruang/latar tempat yang ada dalam film animasi Dalang Pelo Gagas Isengin Acil! Leri Marah! ini adalah ruangan kelas.

2. Pelaku Cerita/Tokoh Film Animasi Dalang Pelo

Berdasarkan segi peranan atau tingkat pentingnya tokoh dalam cerita, pelaku cerita dalam film animasi Dalang Pelo terdiri atas beberapa tokoh sebagai berikut:

a. Tokoh Utama.

Tokoh utama film animasi Dalang Pelo yakni Acil.

b. Tokoh Pendukung/Tambahan

Tokoh pendukung cerita film animasi Dalang Pelo antara lain Leri, Gagas, dan Pak Guru.

Berikut adalah penggambaran tokoh dan penokohan dalam film animasi Dalang Pelo ini: 1. Acil

Acil merupakan sosok remaja SMA laki-laki yang sangat lugu tetapi bawel. la digambarkan sebagai sosok yang sederhana, humoris, dan apa adanya. la juga sosok yang mudah takut dan cemas. Hal yang menjadi unik dari tokoh Acil adalah dia memiliki jamur di atas kepalanya, selalu mengenakan baju yang sama, dan tidak pernah lepas dari penutup kepala. Jamur yang menempel di kepalanya selalu muncul sekalipun dia memakai topi, peci, ataupun helm.

2. Leri

Leri merupakan sosok teman Acil yang selalu dibutuhkan oleh Acil, lebih dewasa dan bisa diandalkan oleh Acil. Leri adalah sosok anak SMA laki-laki seumur Acil tetapi perwatakannya cenderung normal dibandingkan dengan Acil yang sedikit hiperaktif, Leri sedikit bicara dan pintar. 


\section{Gagas}

Gagas merupakan teman sekelas Acil dan Leri. Gagas digambarkan dalam cerita memiliki watak yang jelek, sering mengisengi dan meledek teman-temannya, yaitu Acil dan Leri.

4. Pak Guru

Pak Guru merupakan guru di sekolah Acil, Leri, dan Gagas. Pak Guru memiliki watak yang galak, tegas, dan tidak segan-segan menghukum jika muridnya salah.

5. Tujuan

Tujuan pelaku utama (Acil) dalam episode kali ini adalah membantu Leri membalas keisengan Gagas hingga akhirnya Gagas dihukum Pak Guru, pencapaian tujuan ini dibantu oleh tokoh pendukung yakni Leri dan Pak Guru.

6. Permasalahan dan Konflik

Permasalahan dalam film animasi Dalang Pelo berjudul Gagas Isengin Acil! Leri Marah! muncul ketika Gagas mengisengi dan meledek Acil dengan melemparkan pensil ke kepalanya. Leri kemudian marah dan tidak terima Gagas mengisengi Acil karena Acil tidak mengisenginya. Namun, Gagas malah membuat Acil dan Leri dipukul oleh Pak Guru karena menuduh mereka berisik. Leri tidak terima perbuatan Gagas. Leri mengeluarkan alat untuk menembak Gagas, yaitu sniper dibantu suppressor sniper dari Acil. Akan tetapi, ternyata Gagas memiliki tembakan yang lebih canggih. Acil mengeluarkan jurus menembaknya sampai Gagas pingsan karena merasa jijik dan dihukum oleh Pak Guru. Akhirnya, Acil dan Leri yang menjadi pemenang.

\section{Analisis Struktur Sinematik Film Animasi Dalang Pelo}

\section{Analisis Mise En Scene (Latar/Setting dan Pencahayaan)}

Cerita dalam film animasi Dalang Pelo ini mengambil latar tempat di ruang kelas. Adapun jenis latar/setting yang digunakan dalam film animasi Dalang Pelo ini adalah jenis setting shot on location. Adegan dilakukan pada lokasi yang sesungguhnya dalam bentuk animasi. Latar ini menunjukkan waktu, ruang, serta pembangun mood penonton. Sementara itu, pencahayaan dalam film ini didominasi warna putih dengan cahaya terang sehingga dapat mempertegas bahwa cerita ini pada latar pagi hari dan dalam suasana yang ceria meskipun disisipi unsur tegang, tetapi unsur humor yang melekat menjadikan ketegangan itu beralih ke nuansa ceria. Deskripsi lebih lengkap perpaduan antara setting dan pencahayaan dapat dilihat dari tabel berikut ini. 
Tabel 5. Fungsi Latar/Setting dan Pencahayaan dalam film Animasi Dalang Pelo

\begin{tabular}{|c|c|c|}
\hline Gambar & Latar/setting & Latar/setting \\
\hline & $\begin{array}{l}\text { Ruang Kelas } \\
\text { Setting digambarkan } \\
\text { sebagai latar saat Acil } \\
\text { bernyanyi lagu kembali } \\
\text { sekolah untuk Leri dan } \\
\text { Leri membalasnya dengan } \\
\text { ketus. }\end{array}$ & $\begin{array}{l}\text { Penunjuk ruang dan wilayah } \\
\text { untuk menunjukan kepada } \\
\text { penonton bahwa kejadian } \\
\text { itu terjadi di sekolah } \\
\text { yang jika lebih spesifik } \\
\text { merupakan sebuah ruangan } \\
\text { kelas. } \\
\text { Pencahayaan ini } \\
\text { menunjukkan setting pagi } \\
\text { hari. }\end{array}$ \\
\hline & $\begin{array}{l}\text { Depan Kelas } \\
\text { Setting digambarkan } \\
\text { sebagai latar ketika Pak } \\
\text { Guru memulai pelajaran }\end{array}$ & $\begin{array}{l}\text { Penunjuk bahwa pelajaran } \\
\text { akan dimulai. Cahaya } \\
\text { dibuat terang menguatkan } \\
\text { gambaran cerita berlatar } \\
\text { pagi hari. }\end{array}$ \\
\hline & $\begin{array}{l}\text { Tempat duduk Acil dan Leri } \\
\text { Setting digambarkan } \\
\text { sebagai latar acil dan Leri } \\
\text { yang kesal karena diisengi } \\
\text { Gagas. }\end{array}$ & $\begin{array}{l}\text { Petunjuk suasana yang } \\
\text { mulai memanas diperkuat } \\
\text { dengan dialog dan ekspresi } \\
\text { kesal dari tokoh Leri dan } \\
\text { Acil. } \\
\text { Pencahayaan terang } \\
\text { memperkuat cerita berlatar } \\
\text { pagi hari. }\end{array}$ \\
\hline & $\begin{array}{l}\text { Bagian depan kelas } \\
\text { Setting digambarkan se- } \\
\text { bagai latar Acil saat akan } \\
\text { mengeluarkan jurus men- } \\
\text { embaknya untuk membalas } \\
\text { Gagas. }\end{array}$ & $\begin{array}{l}\text { Petunjuk suasana men- } \\
\text { egangkan yang diperkuat } \\
\text { dengan suara menegang- } \\
\text { kan. } \\
\text { Pencahayaan terang mem- } \\
\text { perkuat cerita berlatar pagi } \\
\text { hari. }\end{array}$ \\
\hline & $\begin{array}{l}\text { Tempat Duduk Gagas } \\
\text { Setting digambarkan } \\
\text { sebagai latar saat Gagas } \\
\text { terkena tembakan Acil dan } \\
\text { merasa jijik sampai pingsan. }\end{array}$ & $\begin{array}{l}\text { Petunjuk suasana mulai } \\
\text { mencair karena Acil berhasil } \\
\text { menembak Gagas hingga } \\
\text { pingsan. } \\
\text { Pencahayaan dibuat redup } \\
\text { untuk menguatkan bahwa } \\
\text { Gagas kalah dari pertempu- } \\
\text { ran menembak }\end{array}$ \\
\hline
\end{tabular}




\begin{tabular}{|l|l|}
\hline $\begin{array}{l}\text { Tempat duduk Acil dan Leri } \\
\text { Setting digambarkan } \\
\text { sebagai latar Acil dan Leri } \\
\text { yang memenangkan per- } \\
\text { tempuran saling menembak } \\
\text { bersama Gagas. }\end{array}$ & $\begin{array}{l}\text { Petunjuk kepuasan Leri } \\
\text { dan Acil karena berhasil } \\
\text { membalas Gagas sampai ia } \\
\text { dihukum. } \\
\text { Pencahayaan dibuat terang } \\
\text { disertai cahaya yang men- } \\
\text { yorot ke arah depan untuk } \\
\text { menunjukan cahaya ke- } \\
\text { menangan. }\end{array}$ \\
\hline
\end{tabular}

\section{Kostum, Tata Rias, Pemain, dan Pergerakannya}

Kostum dan tata rias dalam film ini tampak dalam penggambaran tokoh dan perwatakannya sebagai berikut:

Tabel 6. Tokoh, Kostum dan Tata Rias, serta Pergerakan Pemain

\begin{tabular}{|c|c|c|c|}
\hline Tokoh & Perwatakan & Kostum dan Tata Rias & $\begin{array}{l}\text { Pergerakan } \\
\text { Pemain }\end{array}$ \\
\hline Acil & $\begin{array}{l}\text { Remaja SMA yang sangat } \\
\text { lugu namun bawel. la juga } \\
\text { humoris namun penakut } \\
\text { dan sesali cemas }\end{array}$ & $\begin{array}{l}\text { Acil selalu mengenakan baju } \\
\text { yang sama namun tidak pernah } \\
\text { lepas dari penutup kepala. Yang } \\
\text { unik dari tokoh Acil ini adalah ia } \\
\text { memiliki jamur di atas kepalanya. } \\
\text { Jamur ini selalu muncul } \\
\text { walaupun ia memakai topi, peci, } \\
\text { dan helm. Tata rias wajahnya } \\
\text { layaknya remaja SMA yang polos } \\
\text { dan lugu. }\end{array}$ & $\begin{array}{l}\text { Acil } \\
\text { merupakan } \\
\text { tokoh utama } \\
\text { yang selalu } \\
\text { digambarkan } \\
\text { polos dan } \\
\text { lugu. }\end{array}$ \\
\hline Leri & $\begin{array}{l}\text { Teman Acil yang lebih } \\
\text { dewasa dan dapat } \\
\text { diandalkan namun, } \\
\text { bersikap normal dan } \\
\text { pintar. }\end{array}$ & $\begin{array}{l}\text { Leri selalu mengenakan pakaian } \\
\text { yang sama tetapi rambut leri } \\
\text { yang berwarna hitam selalu } \\
\text { disisir rapi kebelakang. Hal ini } \\
\text { untuk menimbulkan kedewasaan } \\
\text { yang dimiliki Leri. }\end{array}$ & $\begin{array}{l}\text { Berbeda } \\
\text { dengan Acil, } \\
\text { Leri cenderung } \\
\text { bersuara agak } \\
\text { berat dan } \\
\text { selalu terlihat } \\
\text { pintar dalam } \\
\text { menangani } \\
\text { masalah } \\
\text { apapun yang } \\
\text { dihadapi. }\end{array}$ \\
\hline
\end{tabular}




\begin{tabular}{|l|l|l|l|}
\hline Gagas & $\begin{array}{l}\text { Teman sekelas Acil dan } \\
\text { Leri yang iseng. }\end{array}$ & $\begin{array}{l}\text { Gagas memiliki wajah yang bulat } \\
\text { dan pipi yang sedikit tembem } \\
\text { dengan alis tebal, mata bulat, } \\
\text { hidung yang kecil, dan rambut } \\
\text { yang berwarna coklat. Tata rias } \\
\text { wajahnya dibuat agak gelap agar } \\
\text { kesan anak nakalnya muncul. }\end{array}$ & $\begin{array}{l}\text { Gagas selalu } \\
\text { mengisengi } \\
\text { Acil dan Leri } \\
\text { ketika berada } \\
\text { di sekolah saat } \\
\text { sedang belajar } \\
\text { di kelas. }\end{array}$ \\
\hline $\begin{array}{l}\text { Pak } \\
\text { Guru }\end{array}$ & $\begin{array}{l}\text { Guru di sekolah Acil, Leri, } \\
\text { dan Gagas }\end{array}$ & $\begin{array}{l}\text { Pak Guru mengenakan pakaian } \\
\text { berwarna hijau yang sangat } \\
\text { rapi, memiliki wajah yang tirus } \\
\text { dengan sorot mata tajam dan } \\
\text { alis yang tebal dengan kumis. } \\
\text { Tata rias wajahnya dibuat } \\
\text { layaknya guru yang galak dan } \\
\text { tegas. }\end{array}$ & $\begin{array}{l}\text { Pak Guru selalu } \\
\text { memberikan } \\
\text { hukuman } \\
\text { untuk murid- } \\
\text { muridnya } \\
\text { yang tidak } \\
\text { mengikuti } \\
\text { pelajarannya } \\
\text { dengan baik. }\end{array}$ \\
\hline
\end{tabular}

Analisis Sinematologi, Editing, dan Suara.

Animasi Dalang Pelo dalam episode Gagas Isengin Acil! Leri Marah! secara sinematografi tidak terlalu rumit. Teknik kamera yang digunakan untuk menciptakan efek dramatik bertujuan membangun mood penonton. Aspek sinematografi dalam animasi ini tidak terlalu menonjol karena hanya untuk mendukung fungsi dramatik, penyampaian narasi, dan tema cerita dalam animasi. Efek khusus pun tidak terlalu banyak digunakan, yang sangat menonjol dan terlihat adalah pada teknik penyuntingan shot ke shot. Teknik cut yang memperlihatkan shot ketika Acil dan Leri saling menembak dengan Gagas dan akhirnya Acil mengeluarkan jurus menembaknya sampai Gagas pingsan. Sepanjang animasi berlangsung, latar yang digunakan hanya latar di ruang kelas pada pagi hari. Selain itu, jenis suara yang digunakan cukup sederhana dan tidak banyak variasi. Variasi ada hanya pada saat Leri dan Acil saling menembak dengan Bagas dan pada saat Acil menyanyi.

Tabel 7. Jenis Suara, Cara Pengambilan Gambar, dan Proses Editing Film

\begin{tabular}{|c|l|l|l|}
\hline Gambar & Jenis suara & \multicolumn{1}{c|}{$\begin{array}{c}\text { Pengambilan } \\
\text { Gambar }\end{array}$} & Editing Film \\
\hline & $\begin{array}{l}\text { Jenis suara pada } \\
\text { adegan awal ini } \\
\text { dibuat lucu kare- } \\
\text { na Acil menyan- } \\
\text { yikan lagu }\end{array}$ & $\begin{array}{l}\text { Cara pengambi- } \\
\text { lan gambar yang } \\
\text { beruntun dengan } \\
\text { memperlihatkan } \\
\text { latar }\end{array}$ & $\begin{array}{l}\text { Pada adegan } \\
\text { awal ini jenis } \\
\text { editing yang } \\
\text { dilakukan yaitu } \\
\text { penggabungan } \\
\text { dari shot ke } \\
\text { shot berikut- } \\
\text { nya. }\end{array}$ \\
\hline
\end{tabular}




\begin{tabular}{|c|c|c|c|}
\hline (5) & $\begin{array}{l}\text { Jenis suara Pak } \\
\text { Guru yang di- } \\
\text { gunakan dibuat } \\
\text { serak dan tegas } \\
\text { untuk mem- } \\
\text { perkuat watak } \\
\text { Pak Guru yang } \\
\text { galak. } \\
\end{array}$ & $\begin{array}{l}\text { Cara pengam- } \\
\text { bilan gambar } \\
\text { beruntun dengan } \\
\text { memperlihatkan } \\
\text { latar di depan ke- } \\
\text { las saat Pak Guru } \\
\text { akan memulai } \\
\text { pelajaran. } \\
\end{array}$ & $\begin{array}{l}\text { Pada adegan } \\
\text { ini jenis editing } \\
\text { yang dilakukan } \\
\text { yaitu pengga- } \\
\text { bungan dari } \\
\text { shot ke shot } \\
\text { berikutnya. }\end{array}$ \\
\hline & $\begin{array}{l}\text { Jenis suara } \\
\text { pada adegan ini } \\
\text { terdapat efek } \\
\text { menegangkan } \\
\text { untuk membuat } \\
\text { suasana menjadi } \\
\text { tegang karena } \\
\text { Leri dan Acil } \\
\text { akan mem- } \\
\text { balas keisengan } \\
\text { Gagas. }\end{array}$ & $\begin{array}{l}\text { Cara pengambi- } \\
\text { lan gambar pada } \\
\text { adegan ini pun } \\
\text { beruntun dengan } \\
\text { memperlihatkan } \\
\text { latar Leri yang } \\
\text { mengeluarkan } \\
\text { senjata untuk } \\
\text { menembak. }\end{array}$ & $\begin{array}{l}\text { Pada adegan } \\
\text { ini jenis editing } \\
\text { yang dilakukan } \\
\text { yaitu pengga- } \\
\text { bungan dari } \\
\text { shot ke shot } \\
\text { berikutnya. }\end{array}$ \\
\hline & $\begin{array}{l}\text { Jenis suara } \\
\text { pada adegan ini } \\
\text { mendeskripsikan } \\
\text { ketegangan } \\
\text { yang didukung } \\
\text { unsur komedi } \\
\text { karena kepo- } \\
\text { losan Acil yang } \\
\text { mengeluarkan } \\
\text { jurus menem- } \\
\text { baknya. } \\
\end{array}$ & $\begin{array}{l}\text { Cara pengam- } \\
\text { bilan gambar } \\
\text { dengan latar Acil } \\
\text { yang mengelu- } \\
\text { arkan jurus me- } \\
\text { nembak dengan } \\
\text { polos. }\end{array}$ & $\begin{array}{l}\text { Pada adegan } \\
\text { ini jenis editing } \\
\text { yang dilakukan } \\
\text { yaitu pengga- } \\
\text { bungan dari } \\
\text { shot ke shot } \\
\text { berikutnya. }\end{array}$ \\
\hline & $\begin{array}{l}\text { Jenis suara } \\
\text { pada adegan ini } \\
\text { mendeskripsikan } \\
\text { Gagas yang } \\
\text { merasa jijik } \\
\text { karena terkena } \\
\text { tembakan Acil }\end{array}$ & $\begin{array}{l}\text { Cara pengambi- } \\
\text { lan gambar pun } \\
\text { beruntun dengan } \\
\text { memperlihatkan } \\
\text { latar Gagas yang } \\
\text { pingsan. }\end{array}$ & $\begin{array}{l}\text { Pada adegan } \\
\text { ini jenis editing } \\
\text { yang dilakukan } \\
\text { yaitu pengga- } \\
\text { bungan dari } \\
\text { shot ke shot } \\
\text { berikutnya. }\end{array}$ \\
\hline TAHL & $\begin{array}{l}\text { Jenis suara } \\
\text { pada adegan ini } \\
\text { mendeskripsikan } \\
\text { marahnya Pak } \\
\text { Guru kepada } \\
\text { Gagas karena } \\
\text { menuduh Gagas } \\
\text { tertidur di kelas. } \\
\end{array}$ & $\begin{array}{l}\text { Cara pengambi- } \\
\text { lan gambar pun } \\
\text { beruntun dengan } \\
\text { memperlihatkan } \\
\text { latar Pak Guru } \\
\text { yang marah }\end{array}$ & $\begin{array}{l}\text { Pada adegan } \\
\text { ini jenis editing } \\
\text { yang dilakukan } \\
\text { yaitu pengga- } \\
\text { bungan dari } \\
\text { shot ke shot } \\
\text { berikutnya. }\end{array}$ \\
\hline
\end{tabular}




\begin{tabular}{|l|l|l|l|}
\hline Jenis suara & $\begin{array}{l}\text { Cara pengambi- } \\
\text { pada adegan ini } \\
\text { lan gambar pun } \\
\text { menggambarkan } \\
\text { keceriaan karena } \\
\text { beruntun dengan } \\
\text { memperlihatkan } \\
\text { Acil dan Leri } \\
\text { berhasil mem- } \\
\text { balas keisengan } \\
\text { latar Leri dan Acil } \\
\text { Gagas. }\end{array}$ & $\begin{array}{l}\text { yangang dilakukan } \\
\text { yaitu pengga- } \\
\text { bungan dari } \\
\text { dengan cahaya } \\
\text { kemenangan } \\
\text { sang met ke shot } \\
\text { berikutnya. }\end{array}$ & \\
\hline
\end{tabular}

Berdasarkan hasil analisis aspek narasi dan visual animasi Dalang Pelo sebagai salah satu animasi yang dibuat oleh Nur Alif Ramadhan yang merupakan milenial dapat dilihat representasi generasi milenial yang ditemukan sebagai berikut:

1. Narasi cerita dalam animasi dibuat sederhana dengan tiga babak. Hal ini menunjukkan generasi milenial yang kurang menyukai hal-hal yang rumit.

2. Pola waktu yang digunakan adalah pola linear yang bergerak maju. Hal ini menunjukan sifat generasi milenial yang visioner sebagai bentuk kedekatannya dengan teknologi.

3. Durasi film dibuat singkat hanya berkisar $1-2$ menit. Hal tersebut mengantisipasi kebiasaan generasi milenial yang mudah bosan.

4. Cerita dalam film menggunakan kombinasi jenis penceritaan tak terbatas (Omniscient Narration) sehingga penonton diberikan kebebasan untuk mengetahui informasi dalam setiap adegan dengan sudut pandang menyeluruh.

5. Tokoh dan penokohan yang dihadirkan memiliki keunikan dari gaya, cara berbicara, dan sifat yang dihadirkan, seperti halnya generasi milenial yang suka tampilan berbeda, menggunakan bahasa-bahasa gaul yang kekinian dan senang menciptakan hal-hal baru.

6. Sinematografi digunakan untuk mendukung fungsi dramatik, penyampaian narasi, dan tema cerita dalam animasi sehingga para penonton khususnya generasi milenial yang cenderung mudah terbawa perasaan dapat menikmati ceritanya.

\section{SIMPULAN}

Dari analisis aspek narasi dan visual film animasi Dalang Pelo ini, dapat dikatakan bahwa representasi generasi milenial berusaha dihadirkan animator. Pola struktur cerita, segmentasi adegan, tokoh, jenis suara, cara pengambilan gambar, dan lainnya yang dikemas berbeda dan unik, seperti salah satu sifat generasi milenial yang suka tampilan berbeda dan senang menciptakan hal-hal baru. Selain itu, gaya yang ditampilkan oleh tokoh-tokoh animasi ini pun dibuat sedemikian rupa seperti yang dilakukan oleh generasi milenial yang sangat memperhatikan gaya (style) yang akan dipakai.

\section{DAFTAR RUJUKAN}

Ambarwati, A., \& Raharjo, S. T. (2018). Prinsip Kepemimpinan Character of a Leader pada Era Generasi Milenial. PHILANTHROPY: Journal of Psychology, 2(2), 114-127.

Creswell, J. W. (2009). Research Design Qualitative, Quantitative, and Mixed Methods 
Approaches.University of Nebraska-Lincoln: SAGE Publications.

Djalle, Z. G. (2006). The Making of 3D Animation Movie Using 3DstudioMax. Bandung: Informatika.

Hasbullah, H., \& Yasa, G. P. P. A. (2020). Makna Kode Visual dalam Scene Film Animasi "Battle Of Surabaya". Jurnal Bahasa Rupa, 3(2), 124-129.

Hendriana, Y., \& Aziz, M. (2016). Designing 3D Animation of Javanese Shadow Puppets to Learning Cultural Heritage. International Journal of Computer Science and Information Security, 14(10), 507.

Hidayatullah, S., Waris, A., \& Devianti, R. C. (2018). Perilaku Generasi Milenial dalam Menggunakan Aplikasi Go-Food. Jurnal Manajemen dan kewirausahaan, 6(2), 240—249. Khalis, F. M., Mustaffa, N., \& Ali, M. N. S. (2016). The sense of local identity characteristic in Malaysian animation. International Journal of Arts \& Sciences, 9(3), 485.

Lestari, P. A. R., \& Setiawan, I. K. (2019). Adaptasi Cerita Rakyat Jayaprana dan Layonsari dalam Bentuk Animasi 2D. Jurnal Nawala Visual, 1(2), 88-94.

Moleong, J. L. (2012). Metodologi Penelitian Kualitatif. Bandung: Rosdakarya.

Muhdaliha, B., \& Batuaya, D. R. D. (2017). Film Animasi 2 Dimensi Cerita Rakyat Bali Berjudul I Ceker Cipak. Jurnal Bahasa Rupa, 1(1), 61-72.

Othman, A. N. B. (2009). Film Animasi Malaysia: Narasi Verbal ke Visual. ITB J. Vis. Art \& Des, 3(1). 79-88.

Poluakan, M. V., Dikayuana, D., Wibowo, H., \& Raharjo, S. T. (2019). Potret Generasi Milenial pada Era Revolusi Industri 4.0. Focus: Jurnal Pekerjaan Sosial, 2(2), 187-197.

Putra, I. N. A. S., \& Saputra, I. P. A. (2017). Perancangan Media Informasi Program Studi Teknik Informatika Dan Sistem Komputer Pada STMIK STIKOM Indonesia Berbasis Animasi 2D. Jurnal Bahasa Rupa, 1(1), 17-24.

Putri, G. I., \& Candraningrum, D. A. (2019). Pemanfaatan Social Traffic untuk Meningkatkan Page Views Pada Video "Gagasan Isengin Acil! Leri Marah" Di Akun Youtube dan Instagram Dalang Pelo. Prologia, 3(2), 519-524.

Roza, P. (2020). Digital Citizenship: Menyiapkan Generasi Milenial Menjadi Warga Negara Demokratis Di Abad Digital. Jurnal Sosioteknologi, 19(2), 190-202.

Sabani, N. (2018). Generasi Milenial dan Absurditas Debat Kusir Virtual. Informasi: Kajian Ilmu Komunikasi, 48(1), 95-108.

Sangian, J. G., \& Lumenta, A. S. (2017). Film Animasi Tragedi 5 Maret 2014 di Fakultas Teknik. Jurnal Teknik Elektro dan Komputer, 6(4), 205-214.

Sari, S. (2019). Literasi Media pada Generasi Milenial di Era Digital. Profesional: Jurnal Komunikasi dan Administrasi Publik, 6(2), 30—42.

Suryadi, B. (2015). Generasi y: Karakteristik, Masalah, dan Peran Konselor. Seminar dan Workshop Internasional MALINDO 4 di Bali, 22-23 Mei 2015. Diselenggarakan oleh Asosiasi Bimbingan dan Konseling Indonesia (ABKIN).

Winarni, R. W., \& Wardani, W. G. W. (2016). Produksi Film Animasi Sebagai Media Kampanye Anti Kejahatan Perdagangan Manusia. Jurnal Desain, 3(1), 37-48. 